\author{
Nemchenko H. \\ Assistant \\ Department of Management of Business \\ Odessa National Academy of Food Technologies \\ Kanatna str., 112, Odesa, Ukraine, 65039 \\ E-mail: lady.anna.cat@gmail.com \\ ORCID ID: 0000-0003-0407-3744
}

\title{
THE INNOVATIVE WAY OF OVERCOMING OF FOOD INDUSTRY ENTERPRISES PROBLEMS
}

Ukrainian sustainable development envisages the food industry reforming and the formation of a modern structure of the national economy. Regional financial decentralization should help to solve this problem. Fiscal decentralization should optimize the economic interests of agricultural, food businesses, regions and the state. The analysis of the formation of the modern food industry structure in the conditions of financial decentralization was presented in the works of many scientists: both national and foreign ones. However, so far there is no single correct decision. All this makes the problem of improving the structure of the food industry relevant. It has been substantiated that financial decentralization should optimize the economic interests of enterprises, regions and the state. It is impossible to separate the management of the food business and the region. It may be about managing the food business and the region at the same time.

For the rapid development of the food industry, only lending under current conditions is not enough, and sometimes impossible. All this involves the creation of a regional food industry support fund that would stimulate the production and consumption of environmental products, introduce innovative technologies, help to reconstruct, modernize and, in some cases, re-profile enterprises, providing them with benefits, subsidies, and subventions.

Keywords: financial decentralization, food industry, food industry support regional fund, regional policy, enterprise management.

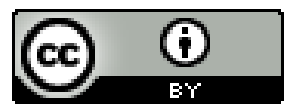

This work is licensed under a Creative Commons Attribution 4.0 International License http://creativecommons.org/licenses/by/4.0/
Statement of the problem and its connection with important scientific and practical tasks. An effective way of competitive struggle in modern economic conditions is innovative development, which envisages the active introduction of the results of scientific activity into the production and commercial activity of enterprises. Today, the innovative way of development is an integral or even decisive component of the economic growth of any country in the world. Experience has shown that only with the wide introduction of innovative developments it is possible to fill both Ukrainian and world markets with competitive domestic production. Instead, at the moment there is a completely different situation: instead of high-tech science-intensive products, domestic exports are mostly represented by semi-finished products of a low level of processing and raw materials, which, in its turn, is the most striking proof of the inappropriate use of natural resources. The solution of these problems will be facilitated by product, technological, managerial, marketing, process innovative, innovative approaches to financial flows management, namely, financial decentralization, which optimizes the economic interests of enterprises. Constant changes in the innovation activity of food industry enterprises in Ukraine re- quire further research in this direction, therefore the subject of the research is relevant.

The analysis of the latest publications on the problem. Analysis of recent publications on the problem. The issues of management of the innovation process and the choice of innovative strategies are disclosed in the writings of such domestic and foreign scholars as Hryn'ov V., Illyashenko S., Bazhal Yu., Lanko O., Hovorukha Zh., Zyatkovs'kyy I. and others. The works of Filipovoyi K., Tovta T., M. Davidovoyi M., Marchenko O. and others who emphasize the necessity of state support of innovation activity are devoted to the problems of innovation development of enterprises.

Forming of the aims of the research. The purpose of the article is to study the role of the state in stimulating the innovation activity of enterprises, the creation of the innovative mechanism for stimulating the production and consumption of environmental products.

Giving an account of the main results and their substantiation. As well as natural and labor resources, the main productive capital of society is the scientific and technological progress. In foreign and domestic literature, it is associated with the concept of the innovation process. 
According to the Ukrainian legislation, innovations are newly developed or improved competitive technologies, products, services or organizational and technical solutions that significantly improve the structure and quality of production or social sphere.

Food business management depends on the structure and efficiency of the economy, region and location, namely:

- natural and climatic environment;

- demographic;

- innovative factors and others.

Therefore, and management should be carried out considering optimization of interests of regions and the state.

Increasing the efficiency of material production and ensuring the competitiveness of products is based on the use of new high-tech equipment and advanced technology, the application of modern organizational forms and economic methods of management. Improvement of production is carried out based on innovation activity [11].

In 2017 , by types of economic activity of innovative types of food products, $21.4 \%$ was introduced. This is a rather low indicator, as the main source of financing innovation costs is the company's own funds [10]. Consequently, the incentives are necessary as well as interests and opportunities to increase this indicator.

It is ideal, if personal, collective (business), region, country, planet interests coincide. In Soviet times, it was considered that personal, collective and regional interests should be oriented only on the state, but, unfortunately, in real life - did not always coincide. The discrepancy between economic and personal interests leads to problems at the enterprise. In the situation in which the economic collective, regional and state interests are in conflict, the probability of the emergence of problems in the region and the country is great. If, however, there is a contradiction in the economic interests of the country and the planet, it contributes to the global problem (environmental, food, military), which demands in the future the creation of a planetary government to avoid dangerous situations.

Taking into account the experience of other countries, in Ukraine, local decentralization of regional governance was proposed, and, first, the financial one, which should optimize the economic interests of enterprises, regions and the state.

In our opinion, financial decentralization should be based on the principles:

- independence;

- material incentives;

- financial responsibility;

- control over the implementation of social projects.

The peculiarity of food enterprises is that they help to solve environmental problems (otherwise it is impossible to produce high-quality products) and at the same time, reduce the morbidity and mortality of the population (to save on funding for health care), contribute to GDP growth. According to Bondar V., the basis of the green initiative of production includes the following prin- ciples: planning and complexity; rationality of production placement; territorial approach; study of changes that can affect the health and living conditions of people; carrying out of ecological examination of projects [1, p.323].

All these suggest that it is impossible to separate the management of the food business and the region. At the same time, the food industry is influenced by the structure of the country's economy. The lack of modern industries capable of supplying innovative technologies and sometimes low-quality raw materials, an unfavorable investment climate impede the development of the food industry. As Kholod B. emphasizes "the criteria of public assessment of labor costs is changed qualitatively: if earlier its value was measured, first of all, by the cost of the product, then now not only the labor productivity has importance but the effective use of energy, raw materials and materials that depend entirely on the level of knowledge, professional behavior and people's intelligence, and the potential of technologies created by people" $[4, \mathrm{p}$. 43]. Unfortunately, food products' consumers have low paying capacity and do not demand high quality. Therefore, Ukrainian food companies are unable and unwilling to implement innovative technologies and produce highquality (environmentally friendly and safe for health) products, and regions and the country cannot expect significant revenues to the budget.

The food industry's structure does not meet modern requirements. During the period of Ukrainian independence, the share of crop production increased and declined significantly from livestock breeding. This is due to the low paying capacity of the population, the lack of investment climate and to the specifics of the industry - high capital-output ratio in the production of cattle, when the first profit is obtained in 2-3 years.

Ukraine exports a lot of grain, and does not, recycle a larger share of grain in the country. As a result, the country "lacks" cheap quality livestock products and is forced to import, which is more expensive than grain. The poor logistics, which increases the price of "delivery" to ports (this is due to poor roads and high railroad transportation costs), also reduces the efficiency of our grain exports. All this reduces export earnings. The use of grain for the cultivation and production of livestock products would contribute to filling the budget of the country and regions, would allow to allocate funds for the modernization of ports, roads, railways, and would improve export efficiency. To do this, the state should stimulate food businesses and agriculture to process grain, use it in the country with taxes, which will make the export of raw materials ineffective. At the same time, the state is obliged to establish export limits in order to protect the national grain market and provide raw materials for domestic food businesses and livestock. At the same time, it is necessary to "take into account" the content of humus from economic activity. For the deterioration of humus content, farmers should be charged with additional taxes. It will also contribute to rational land use. It will be less beneficial to grow oilseeds (sunflower, rape) and to export oils as they destroy the quality of the soil and the possibility of obtaining high yields in the future.

So, for today, Ukraine is on the verge of lifting 
the moratorium on land sales. This is ambiguous for the further development of our country. Despite the positive aspects, many are negative and need to be considered. For example, Nemchenko V. emphasizes such issues as:

1. There is no appropriate legislative framework to regulate this process. Thus, Ukrainians can become "guests" in their own country. And, most importantly, the land will be sold for "no price", as there is no appropriate modern method for determining the value of land.

2. Most people are not able to buy land because of financial difficulties: since they are below the poverty line. And those peasants who consider the sale of land as a solution to this problem, will lose land at no cost, after the expiry of the lease will receive spoiled areas that will not be possible to use for the cultivation of crops [7].

The specified risks have directly proportional influence on formation and further development of food enterprises in Ukraine.

It is expected that the climate warming in Ukraine will lead to an increase in droughts, and the destruction of forest networks (using them for winter heating, which is associated with high utility tariffs) will promote soil erosion and in the long run, will reduce crops and provide raw materials to food businesses, and together will negatively affect the reproduction of manpower. In this negative direction there will be an increase in landfill waste, pollution of reservoirs, almost no utilization. As a result, in the absence of waste management, the area to produce crops and livestock will be further reduced.

The use of sapropel, vermiculture and biological plant protection products opens wide opportunities in increasing yields and providing ecological raw materials to food companies. In Korchyns'kyy's A. opinion: "A balanced model of agricultural development is based on the careful management of all limited resources to prevent their being wasted and degraded, avoiding excessive fertilization ... to minimize pollution of soil and water" [2, p.30].

The technology of using Californian worms, which processes all organic matter (including food industry waste), cleans the soil and increases its fertility arouses special interest. The value of the earthworm is that, in addition to a balanced composition of amino acids, it more than $70 \%$ consists of proteins. After cleaning and drying the biomass of the worm is used as a feed for animals and fish and as additives to some types of food products. In many countries of the world (USA, England, Germany, Italy, Spain and others) earthworms are most effectively used to obtain bio humus from community's waste, vegetable bases, vegetable matter and other garbage. Breeding and selling only earthworms bring to one billion dollars profit in the world [2, p. 30].

Automation has a huge potential for transforming agriculture. The use of robots for landing, harvesting and processing of grain will make this process more efficient and easier to carry out on the scale needed to feed the growing world population. Robots can also be used to monitor the growth of crops. There are proposals for the use of micro robots for this purpose, to optimize the monitoring of crop production [8]. Remote control techno- logy of fields are already in use in India. There, they track the condition and level of damage to crops. And insurance companies use them to more objectively evaluate farmers' claims for compensation for damage they cause [9].

We believe that Ukrainian food enterprises should pay attention to one more innovative idea - vertical farms. They are already used in countries such as Japan, where there is little space. Cultures are grown inside multi-storey buildings such as high-rise and skyscrapers, in rooms with artificial lighting or in vertical greenhouses. With the growth of urbanization and the global population, this trend will be even more relevant [8].

This suggests that agricultural and food companies are also interested in forest networks, irrigated land, the destruction of existing waste landfills, and the reduction of pollution of reservoirs, which requires huge amounts of money. Each individual enterprise is not able to solve the listed problems. For the rapid development of the food industry, only lending under current conditions is not enough, and sometimes impossible.

To date, there are still important problems that hamper the development of the banking system. Among them: insufficient level of capitalization, high level of dollarization, low level of protection of the rights of creditors, a significant proportion of low-quality assets, low financial literacy of the population, distrust to the banking sector and others [6].

All this envisages the creation of a regional food industry support fund (FISF) that would stimulate the production and consumption of environmental products, the introduction of innovative technologies, would help to reconstruct, modernize, and in some cases, re-profile enterprises, providing them with concessions in the form of benefits, subsidies for subventions.

Real creation of additional jobs, introduction of innovative technologies and production competitive environmental products are the conductions of such assistance. The well-known scientist Makarenko P. has a similar point of view, he writes: "The starting point for irreversible budget allocations is the creation of special funds for supporting the agrarian sector at national and regional levels" [3, p. 649].

The sources of FISF could be partly regional funds, $1-2 \%$ deductions from the profits of food, agricultural enterprises, regional environmental funds, savings made from improving the health of the population, as well as taxes, duties on exports of raw materials.

The creation of the FISF will contribute to the balance, "overflow" of capital to the "needed" industry, which determines not only the market (for profit), but also the society - the regions and the state. For the food industry to have a stable development, machinery must provide innovative technologies and enhance competitiveness. Therefore, in these conditions, the importance of the state, which is obliged to establish plans and forecasts of the food industry of the country and to help, is growing.

In our opinion, FISF will facilitate the cooperation of agricultural and food businesses. This will make it possible to improve land cultivation, use modern 
equipment and technology, provide the food industry with high-quality raw materials, and protect the interests of entrepreneurs.

Cooperation can be aimed at creating green energy (using solar, air energy, biogas on farms, etc.), which will significantly reduce the cutting down forest networks in the winter. All this suggests that in the region, entrepreneurs should independently establish cooperatives that are interested in attracting their own funds, FISF, and in some cases loans and issuing regional securities.

Conclusions and prospects of the further investigations. Consequently, the results of the study determined the role of financial decentralization in optimizing the economic interests of food businesses. Financial decentralization should be based on the principles of: independence; material interest and responsibility; control over the implementation of social projects. It is proved that Ukrainian food companies are not interested in introducing innovations.

For the rapid development of the food industry, only lending under current conditions is not enough, and sometimes impossible. All of this involves the creation of a regional food industry support fund that would stimulate the production and consumption of environmental products, introduce innovative technologies, help to reconstruct, modernize and, in some cases, re-profile enterprises, providing them with benefits in the form of concessions, subsidies, and subventions.

\section{References}

1. Bondar, V. A. (2017). Napriamy vprovadzhennia «zelenoi» modernizatsii na pidpryiemstvakh zernopererobnoi haluzi. In I. I. Savenko \& H. M. Stankevych (Eds.), Rekonstruktyvnyi typ adaptuvannia realnoho sektoru ekonomiky ta haluzevoi nauky Ukrainy do umov postindustrialnoho suspilstva (pp. 348-364). Odesa: KP «Odeska miska drukarnia».

2. Korchynskyi, A. A. (2001). Pro ekolohizatsiiu ratsionalnoho zemlekorystuvannia. Ekonomika APK,(3), 27-30.

3. Makarenko, P. M. (2005). Modeli ahrarnoi ekonomiky. Kyiv: NNTs «Instytut ahrarnoi ekonomiky».

4. Tkachenko, V. A. (2013). Teoriia nevyznachenosti v skladnykh samorehuliuiuchykh sotsialnoekonomichnykh systemakh. In V. A. Tkachenko (Ed.), Teoriia proektuvannia velykykh samokerovanykh sotsialnoekonomichnykh system. Dnipropetrovsk: Monolyt.

5. Nemchenko, V. V., \& Nemchenko, H. V. (2017). Investment potential of Ukraine and the possibility of its use. Food Industry Economics, 9(4), 68-72. doi:10.15673/fie.v9i4.746

6. Nemchenko, V. V. (2017). Problemy bankivskoho kredytuvannia ekonomiky Ukrainy. In V. V. Nemchenko (Ed.), Rozvytok finansovoi systemy suchasnoho pidpryiemstva: Oblikovo-analitychnyi aspekt (pp. 24-29). Odesa: Feniks.

7. Nemchenko, V. V. (2018). Problemy formuvannia tsyvilizovanoho rynku zemli v Ukraini. Ekonomichna Ta Prodovolcha Bezpeka Ukrainy, 6(3-4), 3-9.

8. Technology that Will Change Agriculture in 2017. (2017, March 22). Retrieved December 19, 2018, from http://fafdl.org/blog/2017/03/22/technology-that-will-change-agriculture-in-2017/

9. Yak tekhnolohii zminiuiut silske hospodarstvo. (2017). Retrieved January 14, 2019, from http://www.bakertilly.ua/news/id1292

10. Naukova ta innovatsiina diialnist Ukrainy. (2018). Retrieved February 05, 2019, from http://www.ukrstat.gov.ua/druk/publicat/kat_u/2018/zb/09/zb_nauka_2017.pdf

11. Sulima, N. M., Stepasiuk, L. M., \& Velychko, O. V. (2015). Ekonomika i finansy pidpryiemstva. Kyiv: TsP «KOMPRYNT».

Received 10 February 2019

Approved 24 February 2019

Немченко А.B.

ассистент

кафедра управления бизнесом

Одесская национальная академия пищевых технологий

ул. Канатная, 112, г. Одесса, Украина, 65039

E-mail: lady.anna.cat@gmail.com

ORCID ID: 0000-0003-0407-3744

\section{ИННОВАЦИОННЫЙ ПУТЬ ПРЕОДОЛЕНИЯ ПРОБЛЕМ ПРЕДПРИЯТИЙ ПИЩЕВОЙ ПРОМЫШЛЕННОСТИ}

Устойчивое развитие Украины предусматривает рефрормирование пищевой промышленности, формирование современной структуры народного хозяйства. Помогать в решении этой проблемы должна фринансовая децентрализация регионов. Финансовая децентрализация должна оптимизировать экономические интересы сельскохозяйственных, пищевых предприятий, регионов и государства. Данной проблемой занимается много ученых: как отечественных, так и зарубежных. 
Впрочем, пока нет единого правильного решения. Все это делает проблему совершенствования структуры пищевой промышленности актуальной. Обосновано, что фринансовая децентрализация должна оптимизировать экономические интересы предприятий, регионов и государства. Невозможно отделять управления пищевым предприятием и регионом. Речь может идти об управлении пищевым предприятием и регионом вместе.

Пищевые предприятия, как и экономика Украины в целом, остаются инновационно и инвестиционно неблагоприятными. Государство должно стимулировать пищевые предприятия перерабатывать зерно, употреблять его в стране с помощью налогов, сделает неэффективным экспорт сырья. При этом государство обязано устанавливать границы экспорта, чтобы защитить национальный рынок зерна и обеспечить сырьем отечественные пищевые предприятия и животноводство.

Для стремительного развития пищевой промышленности только кредитования в современных условиях недостаточно, а иногда и невозможно. Все это предполагает создание регионального фонда поддержки пищевой промышленности, который бы стимулировал производство и потребление экологической продукции, внедрение инновационных технологий, помогал реконструировать, модернизировать, а в некоторых случаях перепрофилировать предприятия, оказывая им помощь в виде льгот, дотаций, субвенций.

Ключевые слова: финансовая децентрализация, пищевая промышленность, региональный фронд поддержки пищевой промышленности, региональная политика, управление предприятиями.

\section{Немченко Г.В.}

асистент

кафедра управління бізнесом

Одеська національна академія харчових технологій

вул. Канатна, 112, м. Одеса, Україна, 65039

E-mail: lady.anna.cat@gmail.com

ORCID ID: 0000-0003-0407-3744

\section{ІННОВАЦІЙНИЙ ШЛЯХ ПОДОЛАННЯ ПРОБЛЕМ ПІДПРИЄМСТВ ХАРЧОВОЇ ПРОМИСЛОВОСТІ}

Сталий розвиток України передбачає реформування харчової промисловості, фрормування сучасної структури народного господарства. Допомагати у вирішенні цієї проблеми повинна фінансова децентралізація регіонів. Фінансова децентралізація повинна оптимізувати економічні інтереси сільськогосподарських, харчових підприємств, регіонів та держави. Даною проблемою займається багато вчених: як вітчизняних, так і зарубіжних. Втім поки що немає єдиного правильного рішення. Все це робить проблему удосконалення структури харчової промисловості актуальною. Обґрунтовано, що фінансова децентралізація повинна оптимізувати економічні інтереси підприємств, регіонів та держави. Неможливо відокремлювати управління харчовим підприємством і регіоном. Мова може йти про управління харчовим підприємством та регіоном разом.

Харчові підприємства, як і економіка України в цілому, залишаються інноваційно та інвестиційно несприятливими. Держава повинна стимулювати харчові підприємства переробляти зерно, вживати його в країні за допомогою податків, що зробить неефективним експорт сировини. При цьому держава зобов'язана встановлювати межі експорту, щоб захистити національний ринок зерна і забезпечити сировиною вітчизняні харчові підприємства та тваринництво.

Для стрімкого розвитку харчової промисловості лише кредитування у сучасних умовах недостатньо, а іноді і неможливо. Все це передбачає створення регіонального фонду підтримки харчової промисловості, який би стимулював виробництво і споживання екологічної продукції, впровадження інноваційних технологій, допомагав реконструювати, модернізувати, а в деяких випадках перепрофілювати підприємства, надаючи їм допомогу у вигляді пільг, дотацій, субвенцій.

Ключові слова: фінансова децентралізація, харчова промисловість, регіональний фонд підтримки харчової промисловості, регіональна політика, управління підприємствами.

\section{Література}

1. Бондар В.А. Напрями впровадження «зеленої» модернізації на підприємствах зернопереробної галузі // Реконструктивний тип адаптування реального сектору економіки та галузевої науки України до умов постіндустріального суспільства: монографія / за ред. Савенка I.I., Станкевича Г.М. Одеса: КП «Одеська міська друкарня», 2017. С. 348-364, 644 с. 
2. Корчинський А.А. Про екологізацію раціонального землекористування // Економіка АПК. 2001. Вип. 3. С. 27-30 $2005.682 \mathrm{c}$

3. Макаренко П.М. Моделі аграрної економіки: монографія. Київ: ННЦ «Інститут аграрної економіки»,

4. Ткаченко В.А. Теорія невизначеності в складних саморегулюючих соціально-економічних системах // Теорія проектування великих самокерованих соціально-економічних систем: монографія / за ред. Ткаченко В.А. та ін. Дніпропетровськ: Монолит, 2013. 264 с.

5. Немченко В.В., Немченко Г.В. Investment potential of Ukraine and the possibility of its use // Food Industry Economics. 2017. Vol.9, Issue 4. P. 68-72. DOI: 10.15673/fie.v9i4.746

6. Немченко В.В. Проблеми банківського кредитування економіки України // Розвиток фінансової системи сучасного підприємства: обліково-аналітичний аспект: монографія / за ред. д.е.н., проф. В.В. Немченка. Одеса: Фенікс, 2017. С. 24-29

7. Немченко В.В. Проблеми формування цивілізованого ринку землі в Україні // Економічна та продовольча безпека України. 2018. Т.6, вип.3-4. С.3-9

8. Technology that Will Change Agriculture in 2017 // Food and Farm Discussion Lab. 2017. URL: http://fafdl.org/blog/2017/03/22/technology-that-will-change-agriculture-in-2017/ (date accessed: 19.12.2018).

9. Як технології змінюють сільське господарство // Baker Tilly International: [Веб-сайт]. 2017. URL: http://www.bakertilly.ua/news/id1292 (дата звернення: 14.01.2019).

10. Державна служба статистики України: [Веб-сайт]. 2018. URL: http://www.ukrstat.gov.ua/druk/publicat/kat_u/2018/zb/09/zb_nauka_2017.pdf (дата звернення: 05.02.2019).

11. Суліма Н.М., Степасюк Л.М., Величко О.В.Економіка і фінанси підприємства: підручник. К.: ЦП «КОМПРИНТ, 2015. 466 с.

Стаття надійшла 10.02.2019

Стаття прийнята до друку 24.02.2019

Доступно в мережі Internet 19.03.2019

Цитування згідно ДСТУ 8302:2015

Nemchenko H. The innovative way of overcoming of food industry enterprises problems // Food Industry Economics. 2019. Vol.11, Issue 1. P. 105-110; doi: 10.15673/fie.v11i1.1301

Cite as APA style citation

Nemchenko H. (2019). The innovative way of overcoming of food industry enterprises problems. Food Industry Economics, 11(1), 105-110; doi: 10.15673/fie.v11i1.1301 